\title{
Identification of $\mathrm{GABA}_{\beta}$ Receptor Protein and Farnesol in the Preputial Gland of Bandicoot Rat (Bandicota indica)
}

\author{
Ponnirul Ponmanickam ${ }^{1,2}$, Samuthirapandi Muniasamy ${ }^{1,3}$, Thangavel Rajagopal ${ }^{1,4}$, \\ Rengasamy Lakshminarayanan Rengarajan ${ }^{1}$, Govindaraju Archunan ${ }^{\text {** }}$
}

\begin{abstract}
${ }^{1}$ Department of Animal Science, Center for Pheromone Technology, Bharathidasan University, Tiruchirappalli 620 024, Tamil Nadu, India ${ }^{2}$ Department of Zoology, Ayya Nadar Janaki Ammal College (Autonomous), Sivakasi 626 124, Tamil Nadu, India ${ }^{3}$ Department of Microbiology, Ayya Nadar Janaki Ammal College (Autonomous), Sivakasi 626 124, Tamil Nadu, India ${ }^{4}$ Department of Zoology, Thiagaraja College (Autonomous), Madurai 625 009, Tamil Nadu, India
\end{abstract}

Copyright $(2016$ by authors, all rights reserved. Authors agree that this article remains permanently open access under the terms of the Creative Commons Attribution License 4.0 International License

\begin{abstract}
Preputial gland is one of the prime sources of pheromones in rats. The study on pheromone identification in preputial gland is well established in laboratory rat, house rat and voles. But the study was lacking in the preputial gland of bandicoot rats. Hence, the present investigation was aimed to identify the volatile and protein profiles of preputial gland of male bandicoot rat. Gas chromatography and mass spectrometry (GC-MS) profiles revealed the presence of 47 volatile compounds in the preputial gland. More specifically, the farnesol was found to be a major compound in the preputial gland which is consistent with previous reports in the preputial gland of few other rodents. The histoarchitecture results showed that the preputial gland of male exhibited more acini cells. The protein profiles of preputial gland showed 12 prominent bands in coomassie brilliant blue stained gel. The low molecular mass protein, $19 \mathrm{kDa}$ has been identified as gamma-amino butyric acid type $\mathrm{B}$ receptor subunit I (GABA $\mathrm{G}_{\beta}$ receptor) by MALDI-ToF analysis. Further, to the best of our knowledge, this is the first time we explored the absence of alpha $2 u$ globulin in the $19 \mathrm{kDa}$ band of preputial gland of bandicoot rat. This is in contrast to the presence of alpha $2 \mathrm{u}$ globulin in the preputial gland of laboratory rat (Rattus norvegicus) as well as house rat (Rattus rattus). The present study concludes that among the volatiles and protein analysis performed in the preputial gland, farnesol appears to be a prominent compound and the $\mathrm{GABA}_{\beta}$ receptor protein was identified in $19 \mathrm{kDa}$ band in bandicoot rats.
\end{abstract}

Keywords Preputial Gland, Volatile Compounds, Proteins, Bandicoot Rat

\section{Introduction}

Animals release their pheromones through the secretory and excretory products. The excretory products such as faeces and urine are the major pheromone sources. In several animals, the secretory sources such as preen gland [37] and uropygial glands [40] in birds, metatarsal glands in sika deer [38], paracloacal glands in crocodiles [12], suprasternal gland in opossums [14], sternal gland in old world monkey [35], labial and scrotal secretions of ringtailed lemur [34], anal gland of polecats [41], flank gland in hamsters [23], chin gland in rabbits [15], cheek glands of lesser bandicoot rats [21] and preputial gland of rat [20] and mice [26] are reported as pheromone sources.

Most of the secretory glands are modified sebaceous glands and are reported as pheromone secretors in animals. They release sebum to outside the body that acts as a transporter of pheromones [36]. Among the secretory glands, preputial gland is reported as a modified sebaceous gland and actively releases the pheromones $[2,30]$. It is located in the prepuce of the male rat hence the name preputial gland. The preputial gland is also proved to be a pheromone source through Olfactory Receptor Neuron (ORN) studies [31]. It is assumed that preputial gland may release its contents through urine. Preputial gland odours play several significant functions such as mother-young interaction for the survival of the young during their prepubertal stage $[7,8$, 9], for individual identification [42, 43], sex attraction [13, $20,44]$ and evocation of aggression after maturity [28].

It is well known that low molecular mass proteins $(17-20$ $\mathrm{kDa}$ ) in the pheromone sources assist the pheromone communication by binding and slow releasing of volatiles for the long term availability of pheromones from the scented sites [1]. These proteins belong to lipocalin family and called as pheromone binding / carrying protein (PBP/PCP) [5]. For instance, the PCP is known as Major Urinary Protein (MUP) in the urine of mice [17], alpha $2 \mathrm{u}$ globulin in the urine of rat [10], Aphrodisin in the vaginal mucus of hamster [6], apolipoprotein D in the sweat of human [39], sweat protein in horse [11] and salivary lipocalin in the salivary gland of boar [24]. 
There are plenty of reports available on the importance of preputial glands in pheromone communication. However, the study of pheromones and proteins in the preputial gland of bandicoot rat, Bandicota indica is not yet undertaken. Hence the present study was aimed to explore the volatile compounds and protein profiles in the preputial gland of bandicoot rat.

\section{Materials and Methods}

\subsection{Animals}

Adult male rats, Bandicoota indica were collected from nearby paddy fields at Bharathidasan University, Tiruchirappalli and housed separately in polypropylene cages $(40 \times 25 \times 15 \mathrm{~cm})$ with $2 \mathrm{~cm}$ of rice husk lining the bottom as bedding material, light on from 6.00 to 18.00 hour, temperature $24 \pm 1^{\circ} \mathrm{C}$, reared with pelleted food (SaiDurga feeds and foods, Bangalore) \& water ad libitum. The bedding material was changed twice a week.

\subsection{Isolation of Preputial Gland}

Six adult intact males were sacrificed by cervical dislocation. Then preputial gland was removed carefully and frozen immediately at $-20^{\circ} \mathrm{C}$ until use.

\subsection{Histology}

The histology of preputial gland was performed by adopting the routine paraffin method [16]. Briefly, Preputial glands were dissected out from the bandicoot rats, fixed in Bouin's fluid fixative immediately after autopsy. After fixation the tissues were transferred to $70 \%$ alcohol. Several changes of $70 \%$ alcohol were given until the yellow color disappeared from the tissues. The tissues were then dehydrated by passing through ascending grades of alcohol, cleared in xylene, infiltrated with molten paraffin, and finally embedded in paraffin wax. Transverse and longitudinal sections with 3-5 $\mu \mathrm{m}$ thickness were obtained using a rotary microtome (Leica, Germany). The sections, thus obtained, were stained in Harris hematoxylen and eosin, dehydrated using alcohol, cleared in xylene and mounted using DPX.

\subsection{Preparation of Tissue Extract}

A crude extract from preputial glands was prepared by homogenization with Phosphate Buffer Saline (PBS) (7.2 pH) under ice-cold conditions, followed by centrifugation at $10000 \mathrm{rpm}$ for $15 \mathrm{~min}$. The clear supernatant was immediately used in the subsequent steps.

\subsection{GC-MS Analysis}

The GC-MS analyses were made in QP-5000 (Shimadzu, Japan).The $2 \mu \mathrm{l}$ of extract was injected into the GC-MS on a $30 \mathrm{~m}$ glass capillary column with a film thickness of $0.25 \mu \mathrm{m}$
(30 m x $0.2 \mathrm{~mm}$ i.d., coated with UCON HB 2000) using the following temperature programme: initial oven temperature, $40^{\circ} \mathrm{C}$ for $4 \mathrm{~min}$, increasing to $250^{\circ} \mathrm{C}$ for $10 \mathrm{~min}$. The GC-MS was under the computer control at $70 \mathrm{eV}$, using ammonia as reagent gas at $95 \mathrm{eV}$ to perform chemical ionization. Identification of unknown compounds is by following libraries such as WILEY7, NIST05 and NIST05s [30].

\subsection{SDS-Poly Acrylamide Gel Electrophoresis}

The total protein concentration was determined by the method of Bradford (1976). The 12\% SDS-PAGE was performed as described by Laemmli, 1970 [22] with slight modifications. $50 \mu \mathrm{g}$ protein was loaded on to the gel. For determination of molecular mass, $4 \mu \mathrm{l}$ of protein standard (protein molecular weight marker-medium range, Genei, Bangalore), was loaded into the gel.

\subsection{MALDI-TOF Mass Spectrometry}

The protein spot at $19 \mathrm{kDa}$ was excised, and then subjected to in-gel tryptic digestion following the method of Armstrong et al. 2005[3]. After tryptic digestion, the mixture of peptides was placed in the MALDI target plate and mixed with the matrix solution. Following calibration of known peptides, the samples were processed and mono-isotopic masses of spectra from the tryptic-digested peptides were acquired for database searching. Based on the results, matching compounds and the suspected sequence of the particular sample were obtained. Statistical evaluation of the results and scoring algorithms using Mascot (Matrix Science Ltd, http://www.matrixscience.com) facilitated the identification of best match.

\section{Results}

A well-developed preputial gland was observed in bandicoot rat and each gland was $2.85-3.2 \mathrm{~cm}$ in length, $1.5-$ $2.1 \mathrm{~cm}$ in width and weighed about $3.5-4.32 \mathrm{~g}$. The morphology of the gland appeared as pyriform (Fig. 1a \& b). The histoarchitecture of this gland revealed the presence of acini cells secreting sebum (Fig. 1c). GC-MS results showed the presence of 47 compounds (Fig.2; Table 1) in the preputial gland. Among the compounds, farnesol was found to be a major compound. The protein profile of preputial gland was also observed for the presence of low molecular mass proteins $(17-20 \mathrm{kDa})$. A very thin band of $19 \mathrm{kDa}$ was observed in the coomassie stained gel (Fig. 3).

This $19 \mathrm{kDa}$ band was excised and subjected to in-gel trypsin lysis for MALDI-ToF analysis. After the MALDI-ToF analysis, the monoisotopic number of spectra were scored.The mascot search showed that the $19 \mathrm{kDa}$ band was gamma-aminobutyric acid type $\mathrm{B}$ receptor $\left(\mathrm{GABA}_{\beta}\right)$ subunit I (Fig.4; Table 2). But we got sequence coverage of $13 \%$ and 9 matching peptides. 


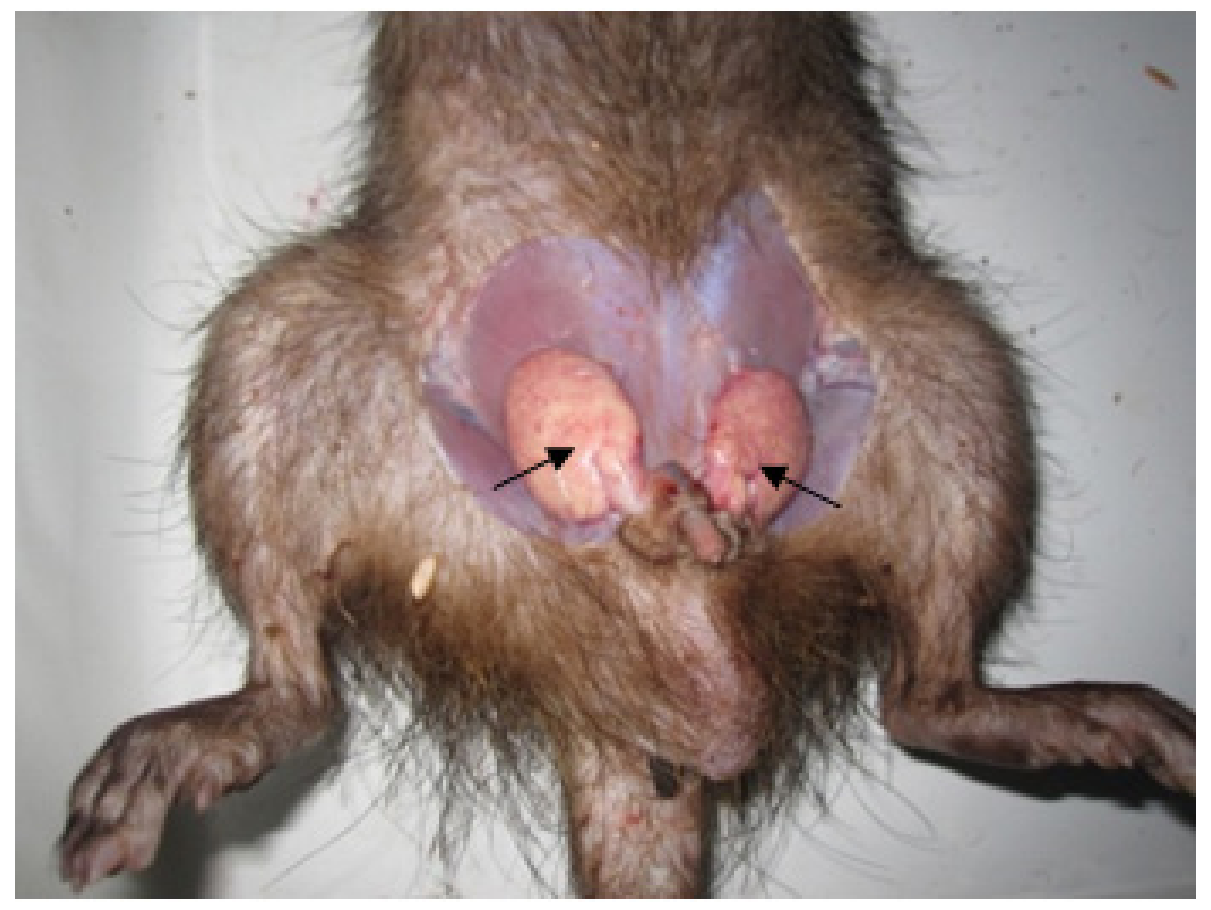

Fig. 1[a]

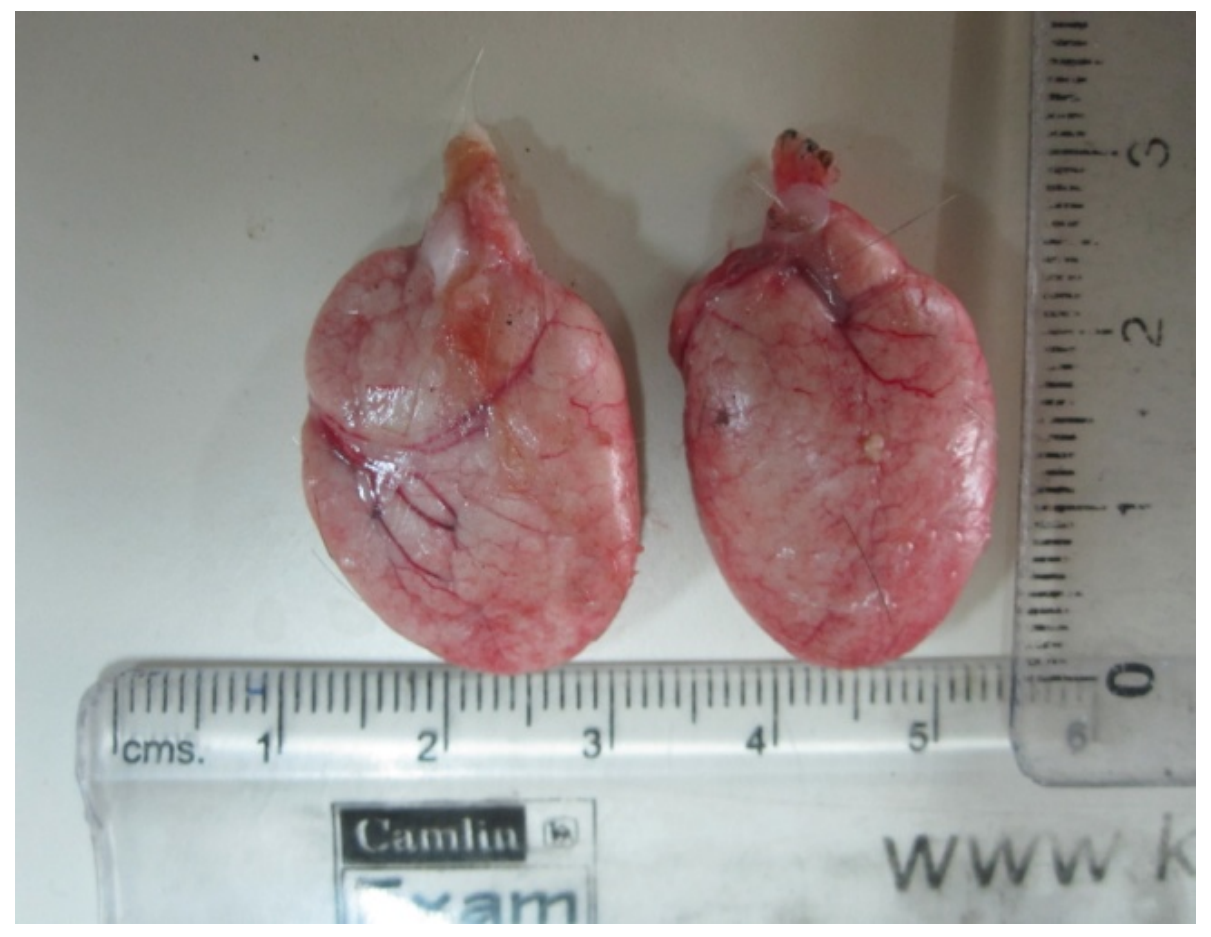

Fig. 1[b] 


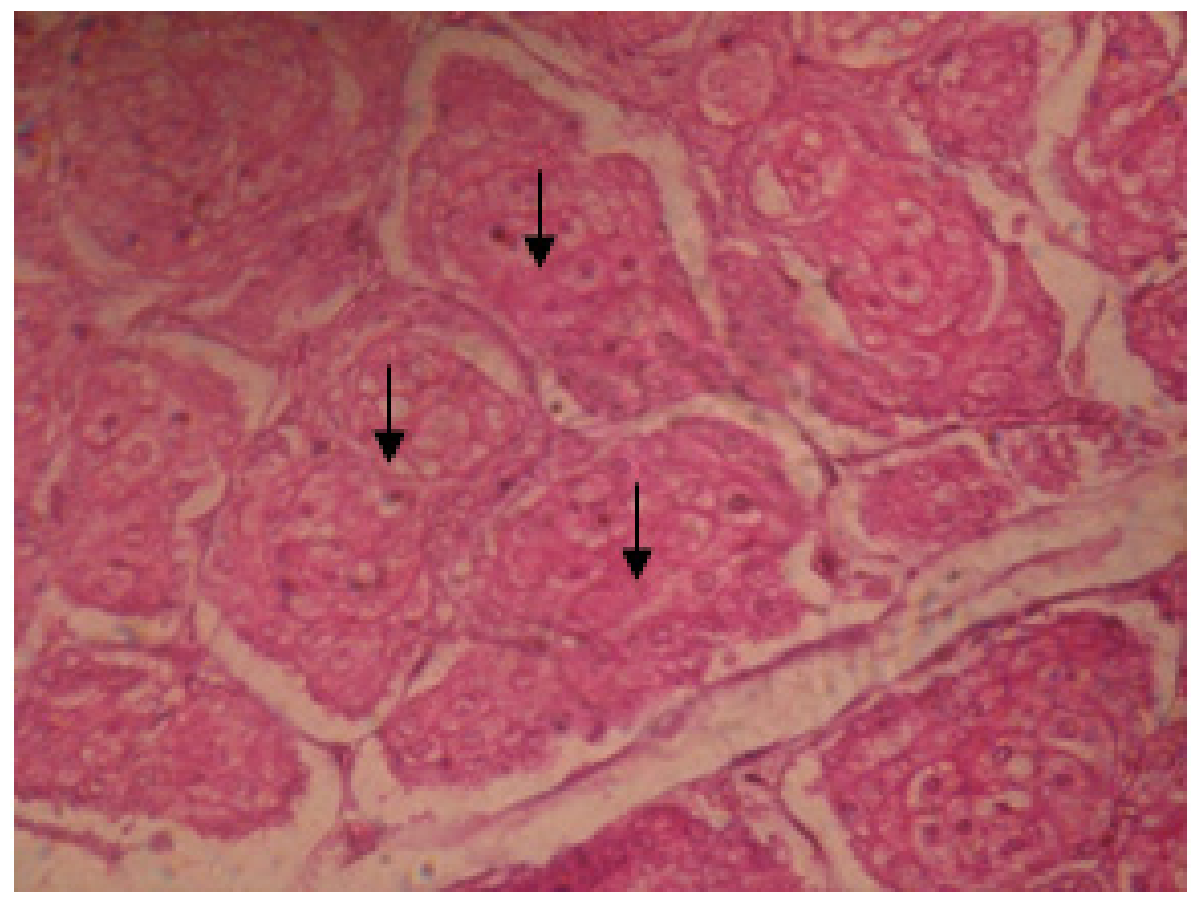

$[\mathrm{c}]$

Figure 1. Morphology of preputial gland [a] Location of preputial gland (arrow); [b] Pear shaped preputial gland; [c] Histoarchitecture of preputial gland (arrow indicates serours acini cells) (40X)

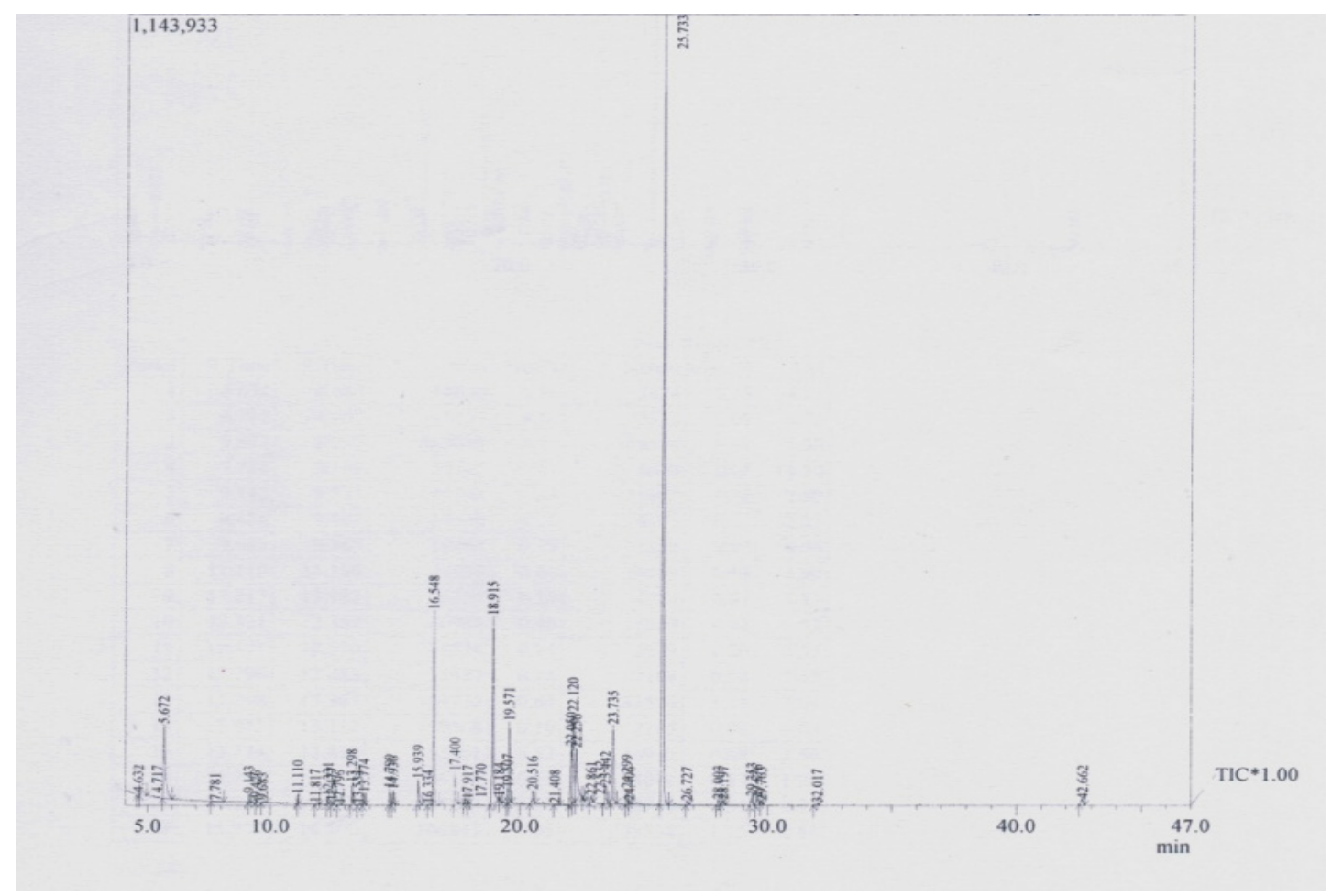

Figure 2. Gas chromatogram of the preputial gland 


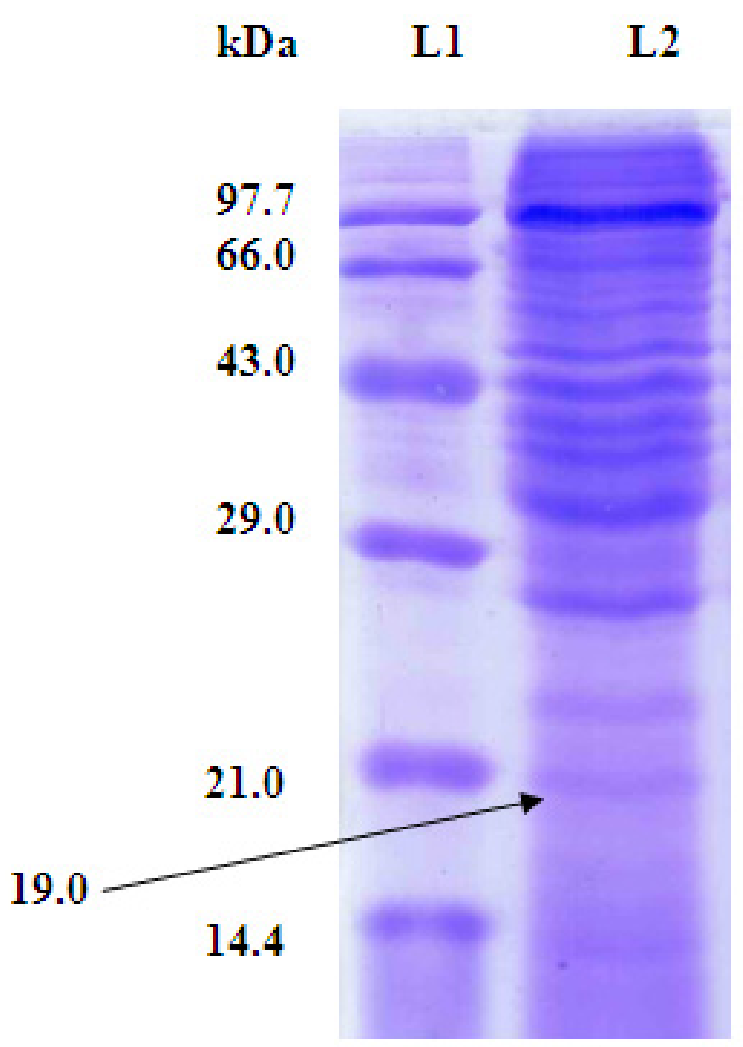

Figure 3. Protein profile of preputial gland of bandicoot rat [L1- molecular weight marker; L2- preputial gland]

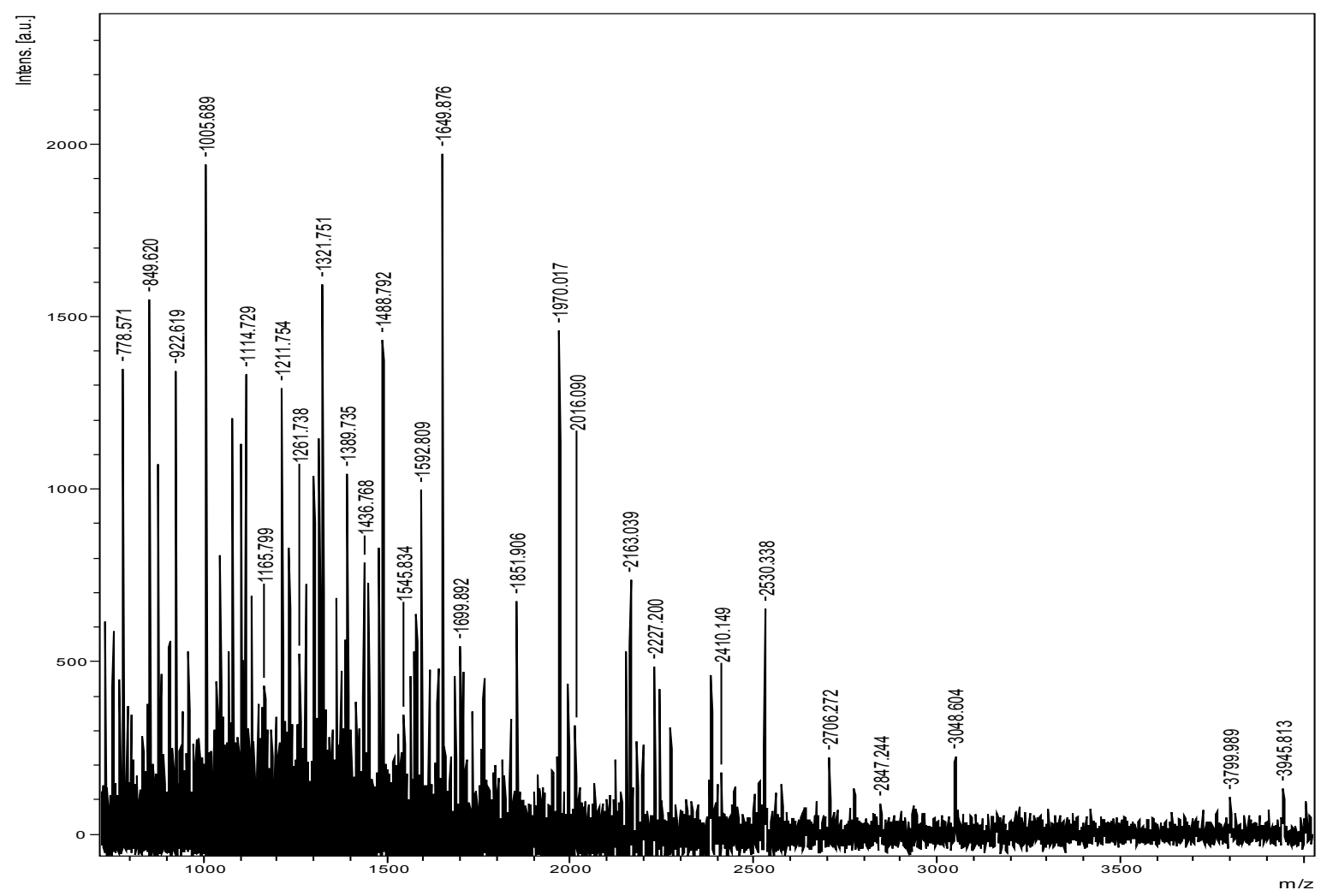

Figure 4. MALDI-TOF mass spectrum of $19 \mathrm{kDa}$ protein band 
Table 1. List of compounds identified in preputial gland of bandicoot rat

\begin{tabular}{|c|c|c|}
\hline S.No. & Retention time & Compounds \\
\hline 1 & 4.633 & 1 Chloro 1-Buten-3-yne \\
\hline 2 & 4.717 & $1,2,3$ Butatriene \\
\hline 3 & 5.667 & 1,4 Dichlorobenzene \\
\hline 4 & 7.783 & 1,1"-Tertricylohexane \\
\hline 5 & 9.150 & Cyclopropane \\
\hline 6 & 9.433 & 3-Aminoheptane \\
\hline 7 & 9.683 & 3-Heptanone \\
\hline 8 & 11.117 & 2 Methyl octane \\
\hline 9 & 11.817 & Diaziridine \\
\hline 10 & 12.333 & 3,4,Dihydropyrane \\
\hline 11 & 12.483 & 2,Decyloxyethanol \\
\hline 12 & 12.800 & Pyrrolidine \\
\hline 13 & 13.300 & Octanoic acid \\
\hline 14 & 13.533 & Difluoromethyldifluoromethanesulphonate \\
\hline 15 & 13.767 & Octyne \\
\hline 16 & 14.800 & Hexanenitrile \\
\hline 17 & 14.933 & 2-Undecanone \\
\hline 18 & 15.933 & Nonanoic acid \\
\hline 19 & 16.333 & 6-Heptan-3-one \\
\hline 20 & 16.550 & Octadecanal \\
\hline 21 & 17.400 & 1 Hexadecanol \\
\hline 22 & 17.767 & 2-propenyloxy ethanol \\
\hline 23 & 17.917 & 2,6,10,11,11-Pentamethyl-2,6,9-dodecatriene \\
\hline 24 & 18.917 & Hexadecanoic acid \\
\hline 25 & 19.183 & 4-Butoxy-1 butanol \\
\hline 26 & 19.500 & 1-dodecanol \\
\hline 27 & 19.567 & Hexadecanal \\
\hline 28 & 20.517 & Stenol \\
\hline 29 & 21.400 & 2-None-1-ol \\
\hline 30 & 22.050 & Silane \\
\hline 31 & 22.117 & 9-Octadecenoic acid \\
\hline 32 & 22.250 & 1,10-Decanediol \\
\hline 33 & 22.533 & 2-Propyldecan-1-ol \\
\hline 34 & 22.867 & 8-Methyl 2- decene \\
\hline 35 & 23.450 & 1,6-Heptadiene \\
\hline 36 & 23.733 & Limoneneoxide \\
\hline 37 & 24.300 & 3-Methyl2-buten-1-ol \\
\hline 38 & 24.400 & 2-Propenoic acid \\
\hline 39 & 25.733 & Farnesol \\
\hline 40 & 26.733 & 2-Methyltetradecane \\
\hline 41 & 28.000 & 1,3-Benzodioxol-2-one \\
\hline 42 & 28.200 & Aziridine \\
\hline 43 & 29.350 & 4-Penten-1-ol \\
\hline 44 & 29.583 & Cyclopentanemethanol \\
\hline 45 & 29.767 & 1,4-Pentadiene \\
\hline 46 & 32.017 & 2-Nitro-1-octanol \\
\hline 47 & 42.667 & 1-Chloro-3-methylbutane \\
\hline
\end{tabular}


Table 2. Sequence coverage and peptide masses of gamma-aminobutyric acid type B receptor subunit 1 [Sequence coverage of $13 \%$ and 9 matching peptides of gamma-aminobutyric acid type B receptor subunit 1 using MALDI-MS data]

$$
\begin{aligned}
& \text { Matched peptides shown in Bold Red } \\
& 1 \text { MLLLLLVPLF LRPLGAGGAQ TPNATSEGCQ IIHPPWEGGI RYRGLTRDQV } \\
& 51 \text { KAINFLPVDY EIEYVCRGER EVVGPKVRKC LANGSWTDMD TPSRCVRICS } \\
& 101 \text { KSYLTLENGK VFLTGGDLPA LDGARVEFRC DPDFHLVGSS RSVCSQGQWS } \\
& 151 \text { TPKPHCQVNR TPHSERRAVY IGALFPMSGG WPGGQACQPA VEMALEDVNS } \\
& 201 \text { RRDILPDYEL KLIHHDSKCD PGQATKYLYE LLYNDPIKII LMPGCSSVST } \\
& 251 \text { LVAEAARMWN LIVLSYGSSS PALSNRQRFP TFFRTHPSAT LHNPTRVKLF } \\
& 301 \text { EKWGWKKIAT IQQTTEVFTS TLDDLEERVK EAGIEITFRQ SFFSDPAVPV } \\
& 351 \text { KNLKRQDARI IVGLFYETEA RKVFCEVYKE RLFGKKYVWF LIGWYADNWF } \\
& 401 \text { KTYDPSINCT VEEMTEAVEG HITTEIVMLN PANTRSISNM TSQEFVEKLT } \\
& 451 \text { KRLKRHPEET GGFQEAPLAY DAIWALALAL NKTSGGGGRS GVRLEDFNYN } \\
& 501 \text { NQTITDQIYR AMNSSSFEGV SGHVVFDASG SRMAWTLIEQ LQGGSYKKIG } \\
& 551 \text { YYDSTKDDLS WSKTDKWIGG SPPADQTLVI KTFRFLSQKL FISVSVLSSL } \\
& 601 \text { GIVLAVVCLS FNIYNSHVRY IQNSQPNLNN LTAVGCSLAL AAVFPLGLDG } \\
& 651 \text { YHIGRSQFPF VCQARLWLLG LGFSLGYGSM FTKIWWVHTV FTKKEEKKEW } \\
& 701 \text { RKTLEPWKLY ATVGLLVGMD VLTLAIWQIV DPLHRTIETF AKEEPKEDID } \\
& 751 \text { VSILPQLEHC SSKKMNTWLG IFYGYKGLLL LLGIFLAYET KSVSTEKIND } \\
& 801 \text { HRAVGMAIYN VAVLCLITAP VTMILSSQQD AAFAFASLAI VFSSYITLVV } \\
& 851 \text { LFVPKMRRLI TRGEWQSETQ DTMKTGSSTN NNEEEKSRLL EKENRELEKI } \\
& 901 \text { IAEKEERVSE LRHQLQSRQQ LRSRRHPPTP PDPSGGLPRG PSEPPDRLSC } \\
& 951 \text { DGSRVHLLYK }
\end{aligned}
$$

\begin{tabular}{|c|c|c|c|c|c|c|}
\hline Start - End & Observed & $\mathrm{Mr}(\mathrm{expt})$ & $\mathrm{Mr}(\mathrm{calc})$ & Delta & Miss & Sequence \\
\hline $95-101$ & 922.6190 & 921.6117 & 921.4524 & 0.1593 & 1 & R.CVRICSK.S 2 (C) \\
\hline $130-141$ & 1389.7350 & 1388.7277 & 1388.6143 & 0.1134 & 0 & R.CDPDFHLVGSSR.S (C) \\
\hline $202-211$ & 1261.7380 & 1260.7307 & 1260.6714 & 0.0594 & 1 & R.RDILPDYELK.L \\
\hline $212-218$ & 849.6200 & 848.6127 & 848.4504 & 0.1623 & 0 & K.LIHHDSK.C \\
\hline $212-226$ & 1649.8760 & 1648.8687 & 1648.7991 & 0.0696 & 1 & K.LIHHDSKCDPGQATK.Y \\
\hline $308-328$ & 2410.1490 & 2409.1417 & 2409.1911 & -0.0494 & 0 & K.IATIQQTTEVFTSTLDDLEER.V \\
\hline $340-351$ & 1321.7510 & 1320.7437 & 1320.6714 & 0.0723 & 0 & R.QSFFSDPAVPVK.N \\
\hline $620-655$ & 3799.9890 & 3798.9817 & 3798.9515 & 0.0302 & 0 & $\begin{array}{c}\text { R.YIQNSQPNLNNLTAVGCSLA- } \\
\text { LAAVFPLGLDGYHIGR.S }\end{array}$ \\
\hline $747-763$ & 1970.0170 & 1969.0097 & 1968.9462 & 0.0635 & 0 & K.EDIDVSILPQLEHCSSK.K (C) \\
\hline
\end{tabular}

\section{Discussion}

In the present study, volatile and protein profiles of preputial gland of bandicoot rat were studied. In this rat, the well-developed pyrifiorm preputial glands were observed. Earlier reports showed that the weight of preputial gland of male laboratory rat was below one gram and it is testosterone dependent [30]. The well-developed preputial gland in bandicoot rat indicates that it may need higher secretion of pheromonal substances from preputial gland for the maintenance of reproductive and dominance status, to attractopposite sex in the open field. It is consistent with the structure of pyriform (pear-shaped) appearance of preputial gland in rats [27]. The pyriform structure of preputial gland may be convenient to store more sebum containing volatiles and proteins.

It is well known that preputial glands are modified sebaceous glands and having the features of broad differentiating cell layer and the continuous maturation of small to large lipid droplets therein [4]. After maturation the acinar cells rupture and release the substances [25]. The sebum released through terminal urethra may get mixed with urine by which the urine acquires preputial originated pheromones and also retains the same on the genitalia.

The identified major compound, farnesol in the preputial gland has already been reported as a bee's sex pheromone in the spider orchid [33]. Similarly, the compounds E-E $\alpha$ farnesene and E- $\beta$ farnesene are analogues to farnesol, reported in mice preputial gland as sex attractant towards female and evoke inter-male aggression [26]. In the preputial gland of house rat (Rattus rattus), the same compound is reported as bound form volatile along with purified alpha $2 \mathrm{u}$ globulin [32]. Based on the present finding and previous reports it is strongly believed that farnesol could be a common volatile produced by preputial gland of rats and mice, therefore, this compound can be considered as male specific preputial originated compound.

The protein profiles of preputial gland of bandicoot rat revealed the appearance of very thin band of $19 \mathrm{kDa}$ protein. It is contrast with high intensity of $19 \mathrm{kDa}$ molecular mass protein reported in laboratory rat [30] and house rat preputial gland $[18,32]$. It is interesting to note that the morphology 
and histoarchitecture of preputial gland of bandicoot rat is consistent with other rats (laboratory and house rats) but the total number of volatiles and protein profile are found to be different while comparing the other reports available in rodent species.

In the present study, the low molecular protein $19 \mathrm{kDa}$ was identified as gamma-aminobutyric acid type B receptor subunit. This protein belongs to G-protein coupled receptor (GPCR) subfamily. Further, the expected $\alpha_{2 u}$-globulin, which has been previously reported in preputial gland of laboratory rat (Rattus norvegicus) and house rat (Rattus rattus), was not identified in the preputial gland of bandicoot rat. Therefore, it is a notable report in rodent biology. The results of present study suggest that the presence of $\alpha_{2 u}$-globulin in the preputial and clitoral gland of rats may be used as a marker to distinguish from other rodent genus Bandicot $\mathrm{sp}$. However, additional work on proteome analysis among rodent species would give more interesting information. Further analysis of major compound, farnesol is required for developing a bio-trap for pest management programme.

\section{Acknowledgement}

This work was supported by grants from University Grants Commission. The facility availed from UGC-SAP DRS-I and DST-FIST Level-I, Government of India is gratefully acknowledged.

\section{REFERENCES}

[1] Archunan, G.A. Vertebrate pheromones and their biological importance. J. Exp. Zool. India 12, 227-239, 2009.

[2] Archunan, G.A., Ponmanickam, P. Preputial gland: A potent pheromone source in rodents (Chapter-12), In: Logan EW and Jason MA (eds.) The Biology of Odors: Sources, Olfaction and Response, Nova Science Publishers, Inc. USA, p 321-340, 2010.

[3] Armstrong, S., Robertson, D., Cheetham, S., Hurst, J., Beynon, R. Structural and functional differences in isoforms of mouse major urinary proteins: a male-specific protein that preferentially binds a male pheromone. Biochem. J. 391, 343-350, 2005.

[4] Atoji, Y., Suzuki, Y., Sugimura, M. The preputial gland of the Japanese serow Capricornis crispus: ultrastructure and lectin histochemistry. Acta Anat (Basel). 134, 245-252, 1989.

[5] Brennan, P.A., Keverne, E.B. Something in the air? New insights into mammalian pheromones. Curr. Biol. 14, R81-R89, 2004.

[6] Briand, L., Huet, J.C., Perez, V., Lenoir, G., Nespoulous, C., Boucher, Y., Trotier. D., Pernollet, J.C. Odorant and pheromone binding by aphrodisin, a hamster aphrodisiac protein. FEBS letters, 476, 179-185, 2000.

[7] Brouette-Lahlou, I., Amouroux, R., Chastrette, F., Cosnier, J., Stoffelsma, J., Vernet-Maury, E. Dodecyl propionate, attractant from rat pup preputial gland: characterization and identification. J. Chem. Ecol. 17, 1343-1354, 1991a.

[8] Brouette-Lahlou, I., Godinot, F., Vernet-Maury, E. The mother rat's vomeronasal organ is involved in detection of dodecyl propionate, the pup's preputial gland pheromone. Physiol. Behav. 66, 427-436, 1999.

[9] Brouette-Lahlou, I., Vernet-Maury, E., Chanel, J. Is rat dam licking behavior regulated by pups' preputial gland secretion? Anim. Learn Behav. 19, 177-184,1991b.

[10] Cavaggioni, A., Mucignat-Caretta, C. Major urinary proteins, alpha (2U)-globulins and aphrodisin. Biochim Biophys Acta $1482,218-228,2000$.

[11] D'Innocenzo, B., Salzano, A.M., D'Ambrosio, C., Gazzano, A., Niccolini, A., Sorce, C., Dani, F.R., Scaloni, A., Pelosi, P. Secretory proteins as potential semiochemical carriers in the horse. Biochemistry 45, 13418-13428, 2006.

[12] García-Rubio, S., Attygalle, A.B., Weldon, P.J., Meinwald, J. Reptilian chemistry: volatile compounds from paracloacal glands of the American crocodile (Crocodylus acutus). $J$. Chem. Ecol. 28, 769-781, 2002.

[13] Gawienowski, A.M., Orsulak, P.J., Stacewicz-Sapuntzakis, M., Joseph, B.M. Presence of sex pheromone in preputial glands of male rats. J. Endocrinol. 67, 283-288, 1975.

[14] Harder, J.D., Jackson, L.M., Koester, D.C. Behavioral and reproductive responses of female opossums to volatile and nonvolatile components of male suprasternal gland secretion. Horm. Behav.54, 741-747, 2008.

[15] Hayes, R.A., Richardson, B.J., Claus, S.C., Wyllie, S.G. Semiochemicals and social signaling in the wild European rabbit in Australia: II. Variations in chemical composition of chin gland secretion across sampling sites. J. Chem. Ecol. 28, 2613-2625, 2002.

[16] Humason, G.L. Animal Tissue Techniques. San Francisco: WH Freeman \& Co. pp. 147-149, 1979.

[17] Hurst, J.L., Payne, C.E., Nevison, C.M., Marie, A.D., Humphries, R.E., Robertson, D.H., Cavaggioni, A., Beynon, R.J. Individual recognition in mice mediated by major urinary proteins. Nature 414, 631-634, 2001.

[18] Kamalakkannan, S., Achiraman, S., Rajkumar, R., Ramesh Kumar, K., Archunan, G. Identification of sex-associated protein in the preputial gland of house rat (a new insight in rodent pest management). Acta Physiol. Hung. 93, 145-152, 2006.

[19] Kannan, S., Archunan, G. Chemistry of clitoral gland secretions of the laboratory rat: assessment of behavioral response to identified compounds. J. Biosci. 26, 247-252, 2001.

[20] Kannan, S., Rameshkumar, K., Archunan, G. Sex attractants in male preputial gland: Chemical identification and their role in reproductive behavior of rats. Curr. Sci. 74, 689-699, 1998.

[21] Kannan, S., Archunan, G. Identification of volatile compounds from cheek glands of lesser bandicoot rats and assessment of behavioural response for identified compounds. Ind. J. Expt. Biol. 37, 798-802, 1999.

[22] Laemmli, U.K. Cleavage of structural proteins during the assembly of the head of bacteriophage T4. Nature 227, 680-685,1970. 
[23] Liu, Y.J., Wang, D.W., Sun, L., Zhang, J.H., Zhang, J.X. Flank gland-secreted putative chemosignals pertaining to photoperiod, endocrine states, and sociosexual behavior in golden hamsters. Curr. Zool. 56, 800-812, 2010.

[24] Marchese, S., Pes, D., Scaloni, A., Carbone, V., Pelosi, P. Lipocalins of boar salivary glands binding odours and pheromones. Eur. J. Biochem. 252, 563-568, 1998.

[25] Montagna, W., Noback, C.R. The histology of the preputial gland of the rat. Anat. Rec.96, 41-54, 1946.

[26] Novotny, M., Harvey, S., Jemiolo, B., Alberts, J. Synthetic pheromones that promote inter-male aggression in mice. Proceedings of the National Academy of Sciences, 82, 2059-2061,1985.

[27] Pietras, R.J. Sex pheromone production by preputial gland: the regulatory role of estrogen. Chem. Senses 6, 391-408, 1981.

[28] Pohorecky, L.A., Blakley, G.G., Ma, E.W., Soini, H.A., Wiesler, D., Bruce, K.E., Novotny, M.V. Social housing influences the composition of volatile compounds in the preputial glands of male rats. Horm. Behav. 53, 536-545, 2008.

[29] Ponmanickam, P., Jebamercy, G., Archunan, G., Kannan, S. Detection of $\alpha_{2 u}$-globulin in rat pup preputial gland by MALDI-TOF mass spectrometry. Curr. Zool. 55, 296-300, 2009.

[30] Ponmanickam, P., Palanivelu, K., Govindaraj, S., Baburajendran, R., Habara, Y., Archunan, G. Identification of testosterone-dependent volatile compounds and proteins in the preputial gland of rat Rattus norvegious. Gen. Comp. Endocrinol. 167,35-43, 2010.

[31] Ponmanickam, P., Archunan, G., Achiraman, S., Sankar, R., Saito, T., Habara, Y. Preputial gland activates olfactory receptor neurons in rat: Calcium imaging study using laser scanning confocal microscopy. Indian J. Biochem. Biophy.50, 242-246, 2013.

[32] Rajkumar, R., Ilayaraja, R., Liao, C.C., Archunan, G., Achiraman, S., Prakash, S., Ng, W.W., Tsay, Y.G. Detection of $\alpha 2 \mathrm{u}$ - globulin and its bound putative pheromones in the preputial gland of the Indian commensal rat (Rattus rattus) using mass spectrometry. Rap. Comm. Mass Spectom. 24, 721-728, 2010.

[33] Schiestl, F.P., Ayasse, M., Paulus, H.F., Löfstedt, C., Hansson, B.S., Ibarra, F., Francke, W. Sex pheromone mimicry in the early spider orchid (Ophrys sphegodes): patterns of hydrocarbons as the key mechanism for pollination by sexual deception. J. Comp. Physiol. A, 186, 567-574, 2000.
[34] Scordato, E.S., Dubay, G., Drea, C.M. Chemical composition of scent marks in the ring tailed lemur (Lemur catta): glandular differences, seasonal variation, and individual signatures. Chem Senses 32, 493-504, 2007.

[35] Setchell, J.M., Vaglio, S., Moggi-Cecchi, J., Boscaro, F., Calamai, L., Knapp, L.A. Chemical composition of scent-gland secretions in an Old World monkey (Mandrillus sphinx): influence of sex, male status, and individual identity. Chem. Senses 35, 205-220, 2010.

[36] Smith, K.R., Thiboutot, D.M. Thematic review series: skin lipids. Sebaceous gland lipids: friend or foe? J. Lipid Res.49, 271-281, 2008.

[37] Whittaker, D.J., Soini, H.A., Gerlach, N.M., Posto, A.L., Novotny, M.V., Ketterson, E.D. Role of testosterone in stimulating seasonal changes in a potential avian chemosignal. J. Chem. Ecol. 37, 1349-1357, 2011.

[38] Wood, W.F. Volatile components in metatarsal glands of sika deer, Cervus nippon. J. Chem. Ecol. 29, 2729-2733, 2003.

[39] Zeng, C., Spielman, A.I., Vowels, B.R., Leyden, J.J., Biemann, K., Preti, G. A human axillary odorant is carried by apolipoprotein D. Proc. Natl. Acad. Sci. USA 93, 6626-6630, 1996.

[40] Zhang, J.X., Wei, W., Zhang, J.H., Yang, W.H. Uropygial gland-secreted alkanols contribute to olfactory sex signals in budgerigars. Chem. Senses 35, 375-382, 2010.

[41] Zhang, J.X., Ni, J., Ren, X.J., Sun, L., Zhang, Z.B., Wang, Z.W. Possible coding for recognition of sexes, individuals and species in anal gland volatiles of Mustela eversmanni and M. sibirica. Chem. Senses 28, 381-388, 2003.

[42] Zhang, J.X., Rao, X.P., Sun, L., Zhao, C.H., Qin, X.W. Putative chemical signals about sex, individuality, and genetic background in the preputial gland and urine of the house mouse (Mus musculus). Chem. Senses 32, 293-303, 2007a.

[43] Zhang, J.X., Zhao, C.H., Rao, X.P., Wang, D.W., Liu, X.H., Qin, X.W., Zhang, Z.B. Possible information about gender and individual recognition coded by insect pheromone analogs in the preputial glands in male Brandt's voles, Lasiopodomys brandtii. Acta. Zool. Sin. 53, 616-624, 2007 b.

[44] Zhang, J.X., Sun, L., Zhang, J.H., Feng, Z.Y. Sex and gonad affecting scent compounds and 3 male pheromones in the rat. Chem. Senses 33, 611-621, 2008. 